\title{
Unknowability, Persecution, and the Ethical Bind: Reading through the Works of Sigmund Freud and Emmanuel Lévinas
}

\author{
Valerie Oved Giovanini \\ California State University, Northridge \\ valerie.giovanini@egs.edu
}

Received 3 January 2018; accepted 14 May 2018; published 30 September 2018.

\begin{abstract}
This paper shows how persecution is a condition that binds each in an ethical obligation. Persecution is functionally defined here as an impinging, affective relation, one that is neither mediated by reason nor open to apology. The works of Sigmund Freud help illuminate the psychological mechanism responsible for impeding rational transparency in delusions of persecution and super-egoical moral demands. Similar to Freud who employs what Paul Ricœur has called a "hermeneutics of suspicion" to interrogate the status of a fully knowing subject, I contend that Emmanuel Lévinas's work on the ethical subject is useful for developing a "hermeneutics of trust" in an ambivalent ontological condition that is unavoidably ethical. By thinking Freud and Lévinas together, I show how the commitment to total mastery of an unknowable ego leads to a persecutory relation, yielding moralities that are unconcerned with injuring the other in the name of that which is judged as good. In answer to this ethical dilemma, I propose that a turn toward relational ethics and an intentionality of search offers traces of a morality where differences are preserved and thus prevent the persecution of the other for one's own moral fulfillment.
\end{abstract}

Keywords: alterity; critical theory; Emmanuel Lévinas; ethics; Paul Ricœur; persecution; philosophy; proximity; Sigmund Freud; subjective unknowability; subjectivity; the other; uncertainty.

\section{The Importance of Freud and Lévinas}

According to Paul Ricœur (1970), Sigmund Freud, along with Karl Marx and Friedrich Nietzsche, was one of the first authors to employ a "hermeneutics of suspicion" in our modern era. By shedding light on the importance of slips of the tongue, parapraxes, dreams, 
denials, negations, and projections, Freud produced a form of both inter- and intra-subjective analysis that revealed the fissures in transparent self-consciousness, unmasking (as Ricœur put it) "the lies and illusions of consciousness" (p. 356). Emmanuel Lévinas takes this hermeneutics of suspicion and joins it with one of faith in the ethical subject.

In this article, I consider how contrasting their ideas on persecution can be valuable for shifting moral considerations to include a hermeneutics of suspicion that regards the self's hidden motives, the insufficiency of abstract and universal moral injunctions, and the inability to calculate consequences. Both Freud and Lévinas question the ideal of a selfsufficient subject and wonder about a subject who is always caught in the asymmetrical relations that accompany social and psychological demands. Freud locates a repressed homosexual component in emotional life as the nucleus of all forms of paranoia that can lead to delusions of persecution as a compensatory psychic measure (1958, p. 59). These components are responsible for building social bonds that begin with others who are similar to oneself. Lévinas similarly characterizes moral relations as beginning with those who are "the same," rather than "other." A fruitful distinction between Freud and Lévinas's works can answer the question of whether or not a subject can reach beyond itself-reach beyond what Lévinas calls the realm of the same - in the affective life it leads.

Persecution is an affective state that both Freud and Lévinas attribute to an embodied subject who always stands in relation to another. A valuable difference between their approaches is Lévinas's thinking through the subject as a primarily ethical entity, incapable of being indifferent to others. With this view of the subject, Lévinas formulates an intentionality of search that negotiates conflicts between the subject's phenomenal and infinite aspects, an idea I will develop in what follows. The subject is persecuted in itself to go toward another in order to become an ethical subject. Even if Freud did not reach the same conclusions about the ethical subject as Lévinas, for both self-mastery through reason is a devalued way of leading a moral life.

After grouping together characteristics of the persecutory subject as unknowable, relational, and vulnerable in both Lévinas and Freud's theories, I ultimately argue that such a view of an inherently and ontologically relational subjectivity can initiate new forms of moral sensibility. For instance, an inherently relational subject can be more attuned to particular vulnerabilities without the precondition of understanding where and how the persecutory relation was formed, a discussion which often leads to inaction and indifference. I also suggest ways in which an intentionality of search can negotiate the ethical relation of proximity for a relational subjectivity that always stands in an asymmetrical relation to the other.

\section{A Comparison between Freud and Lévinas on the Unknowability of the Subject}

In "A Difficulty in the Path of Psycho-Analysis," Freud claims that the "ego is not master in its own house," a consequence that follows from the ability to distinguish one's conscious (or internal) perception of self from what one wills and desires (1955a, p. 143). These can be disjointed because what one is conscious of is "incomplete" and illusory, 
"for the mind is not a simple thing; on the contrary, it is a hierarchy of superordinated and subordinated agencies, a labyrinth of impulses striving independently of one another towards action, corresponding with the multiplicity of instincts and of relations with the external world, many of which are antagonistic to one another and incompatible" (Freud, 1955a, p. 141). Freud argues that there is a fullness of ambivalent phenomena contending within one's self — within a single subject — that can be either unconscious or conscious.

Drives that cannot be discerned are what Freud calls "alien guests" hosted in the ego that cannot be driven away (Freud, 1955a, p. 141). An unconscious mental life that cannot provide trustworthy perceptions is significant because it effectively reduces the certainty of human knowledge and the reliability of psychological virtues. In this way, Freud stated that his work - the work of psychoanalysis - was a general blow to the ego of human knowledge. Difficulties in deciphering the ways in which drives affect the vicissitudes of knowledge production is akin, for Freud, to the Copernican revolution that displaced human understanding from the center of the cosmos, and to the Darwinian upheaval that brought human beings down to the level of the animal (1955a, p. 141).

Freud's contribution in light of this hermeneutics of suspicion was to suggest that more human actions and interactions are capable of conveying meaning with the aid of interpretative work. Meanings that the body communicates are not always trivial, and transparent language is capable of conveying more than the speaker intends, even when lying. Furthermore, Freud not only proposed that these behaviors are meaningful, but also accepted them as positive signs that can lead to the revelation of repressed or unconscious traumas, to the loosening of guilt or fixated concerns. In developing his clinical method, Freud paid special attention to slips of the tongue, negative claims, and narrated examples to reveal the nucleus of his patient's concerns. Freud's work on a psychological biography on neurotic paranoia in delusions of persecution helped him understand the general patterns of psychic deceptions and conditions of unknowability. Here, Freud's writing about the autobiographical account written by Daniel Paul Schreber has the double effect of revealing not only Schreber's paranoia but also Freud's own projected concerns and interests, which are thus freed from the contingencies of an actual patient's life, and possible resistance. In other words, by turning to this "psycho-biography," I can parse general concerns during the time of Freud's life, and find how Freud expressed his own concealed desires by finding them in his "patient" instead.

In the case of Daniel Paul Schreber, Freud suggested that because of homophobic and patriarchal cultural norms, Schreber felt "emasculated" by his wish to assume a passive position during intercourse and was thus led to repress this desire (1955a, p. 45). A defensive struggle in Schreber's psyche ensued that repressed his libidinal homosexual desires. The repressed content of his desire to become like a woman created a libidinal disturbance, and the conflict between his ego and sexual instincts shot back the desire in a pathological form (1955a, pp. 62, 79). Freud argued that the delusions of persecution Schreber experienced during his recovery functioned as a projection of his own guilt onto another: his admired doctor Dr. Flechsig. Dr. Flechsig, who Schreber longed for, became his persecutor. 
The repressed content of the homoerotic phantasy became the conscious content of being abused; the feeling of love turned to hate, and the hate was projected onto Dr. Flechsig as aiming to injure Schreber.

From this, Freud proposed that the root cause of an external and persecuting other was the admonishment in Schreber's own persecuting super-ego. The super-ego persecutes the ego because the latter is incapable of defending itself against desires that are unacceptable. Instead the psyche undertakes a process of projection in which one's internal perception, what was abolished internally, returns from the other. The vicissitudes in knowledge work to conceal unacceptable desires, and the conscious ego cannot perceive these changes in its desires and the objects at which the ego aims.

In this work on Schreber, admonishment through guilt imposed by a super-ego is the affective way social norms impinge on the individual. Along with Freud, we may become suspicious of the possibility that any natural morality will do more than create festering neuroses. Yet, these mechanisms that form delusions of persecution are helpful for understanding how this phenomenon results from the unknowability of oneself. Freud leaves the door open for us to wonder about these "aliens" that that are in the house of the mind. Working with the same type of ambivalence that violently attempts to totalize aspects of an infinite self, Lévinas was able to find grounds in the passivity of the subject that sheds a proverbial blacklight on the condition of unknowability in the formation of self, leading up to its ethical possibilities. It is a blacklight because Lévinas, like Freud, sought those conditions that make any phenomenon possible. On the grounds of what Lévinas calls "the infinite aspects of self," ethical subjectivity will break the masochistic implications of a moral life that Freud found so problematic.

In Existence and Existents (1947), Lévinas acknowledges that a mind composed of conscious and unconscious aspects is a fullness that can "interrupt itself" and have recourse against itself (p. 67). These two oppositional forces, however, are not only contrary to one another, but are also related in their proximity to each other. Lévinas writes in language similar to Freud's, "An abandoned temple is still inhabited by its god, an old house falling into disrepair is still haunted by the ghosts of those who lived there" (1947, p. 26). As an ethical subjectivity, one can take up a sincere intention in one's mere being. A less allegorical example is that when one is hungry, then one can eat.

The subject is an existent who cannot help but take up existence in all its risks of delusion and illusion. Yet there is still always the possibility for Lévinas that "at the very moment when the world seems to break up we still take it seriously and still perform reasonable acts and undertakings; the condemned man still drinks his glass of rum. To call it everyday and condemn it as inauthentic is to fail to recognize the sincerity of hunger and thirst" (Lévinas, 2001, p. 45). The sincerity and value inherent in everyday life leads Lévinas to conclude - unlike Freud - that unconscious mental reservations are on the same spectrum as conscious ones. Conscious acts, then, are riveted; they are potentially interrupted not only by an unpredictable and somewhat trustworthy reality, but also by a mental life that is assured a measure of commensurability with the truthfulness of beings "outside" itself. 
Language and one's mental image of the self can have sincerity to the degree that particular aspects of the self are illuminated, even in their error and delusion, since they represent the preoccupations of the imperialistic ego. Because Lévinas is as comfortable asserting antonyms and ambivalence in the subject as Freud in his theory of drives, he can make the next claim that the present catches up with itself, but with a "lag behind itself, or effects a retreat, a rebound" in the very affects that constitutes oneself (1947, p. 68). Similar to the act of retreating into sleep, the unconscious does not have a separate existence from one's conscious life, but is only enacted "beneath" it (1947, p. 68). Although unconscious mental life participates in the conscious one, it is never a present-participation, similar to the way sleep does not remove one from existence but is only a way of being that is inactive, or passive: a "resting" (Lévinas, 2001, p. 69).

Pushing beyond the egoical self, Lévinas moves towards "passivity prior to the passivityactivity alternative, more passive than any inertia, [and] is described by the ethical terms accusation, persecution, and responsibility for the others" (1998, p. 121). Wherever these dichotomies (or antonyms) of passivity-activity are, the anarchical ethical relation is not. Lévinas develops language with an emphasis placed on proximate knowledge wherein any present-participation of an existent's being and the preoccupations of its imperialistic ego are stunned. The ethical relation is not a negative moment, just as sleep is not a negative moment to the positive standard of wakefulness. In Lévinas's conception of the subject, "this lag that occurs between a being and itself, which we have brought out as the principle characteristic of fatigue, constitutes the advent of consciousness, that is, a power to "suspend" being by sleep and unconsciousness" (1947, p. 30). Note Lévinas's use of quotation marks around the word "suspend" that has the power to create consciousness. Suspension from being is not possible alone. Unconsciousness is equivalent to sleep in its evasion from the light of consciousness; however, the ability to suspend their connection is a mirage.

Whereas for Freud internal drives and their encounters with personal experiences principally motivate the development of an identity, for Lévinas, beyond the egoical self, there is an anonymous plenitude through which there is an infinitely renewable capacity to produce "oneself," to produce events. Lévinas (1947) calls the subject, or self, an infinite task that is given to an infinite regress where freedom is the very need to become identifiable (pp. 84, 86). Contained in what is called the alterity of one's ego is the possibility of the ego's own shattering. Shattering the ego by moving into the proximity of the other, without the attempt to subsume the other, is exactly the risky business of the ethical relation. The relation is risky because there is no guarantee of acknowledgement or reciprocity from the other.

The shattering of one's ego does not resort to deeper sediment layers of the ways one is represented to the self or others, but rather is a preventative measure that bars any definitive identifier from encompassing the total person. Lévinas clarifies thus: "But what is the meaning of non-engagement within the ontological adventure? It is the refusal of the definitive. The world offers me a time in which I traverse different instants, and thanks to the evolution open to me, I am not at any moment definitive. Yet I always carry along my 
past whose every instant is definitive. But, there remains for me, in this world of light, where all is given but where everything is distance" (1947, p. 84). One illustrative example is the quickness with which a radical racist may become tolerant of the very same racial group once hated. All that is required is to go out from the egoical self for an encounter, a moment in which the other is seen in a light where the represented identity as dirty, filthy, or unworthy is relinquished in a re-evaluation of their value. In the readiness with which one may abandon - or conversely adopt - a prejudice, we see the relative arbitrariness identifications can hold for the one conceiving them.

The freedom afforded to any subject is contained in the impossibility of any identifier to totalize what one is. The stronger claim I find Lévinas making is that the ego is an event, an inherent violence forging a self that is vulnerable in this desire to totalize itself under identifiers, regardless of whether they are political, religious, or cultural affiliations. Ethical subjectivity, as such, is vulnerable to this desire. Persecution arises in the self that wants to be totalized in its identifications, but ultimately cannot in the process of becoming what one is: an ethical subject. Though identifications are used to constitute subjectivity, for better or worse, alterity and the ego's shattering preserves its freedom.

Identity starts to take on new forms and meanings for Lévinas. One can ultimately never be identical with oneself because of the pre-ontological alterity of the subject. Many authors have had difficulty reconciling how these two aspects - the pre-ontological and ontological forms of persecution - can reside uncomfortably within one subjectivity for Lévinas. Paul Ricœur calls this the difficulty of reading the otherwise in the title of Lévinas's work (2004, pp. 82-99). Instead of trying to solve this puzzle, I move forward in the assumption that the ontological and pre-ontological forms of persecution are both necessary for ethical subjectivity. The simultaneity of the ontological and pre-ontological forms of persecution allow each self to appear individuated, while also becoming scandalized by this individuation. A self that suffers a pre-ontological persecution for going toward another is scandalous because of the individuated self's turn into an ethical subjectivity, its fulfillment. According to Freud's understanding, on the other hand, the other and moral norms threaten psychic stability

Simon Critchley (1999) illustrates the difficulty Ricœur points out in his article "The Original Traumatism: Lévinas and Psychoanalysis," when he reads the pre-ontological persecutory relation in Lévinas as apiece with the Freudian unconscious. Critchley's article correctly acknowledges that in Lévinas's account of the ethical subject "there is a certain disposition towards alterity within the subject as the structure or pattern of subjectivity" (1999, p. 230). Critchley continues to recognize that Lévinas's account of the ethical subject is constituted in relation to others, which is a trauma to the self-sufficient representations of oneself. Critchley then compares the notion of a subjectivity that is a subjection to the other, waiting in a passivity for a shattering of one's ego to the metapsychology Freud's develops as the second topology in Chapter 5 of Beyond the Pleasure Principle. His work on the first topology of an ego that is formed through identifications and representations cathected to sexual, ego drives shifts after observing traumatic neurosis caused by war. 
Critchley's use of trauma to understand the conclusion of Freud's second topographynamely that death satisfies the aims of all life's drives-compares to Lévinas's ethical subjectivity such that

under the effect of the traumatism of persecution, the deafening shock or the violence of trauma, the subject becomes an internally divided or split self, an interiority that is radically non-self-coincidental, a gaping wound that will not heal, a subject lacerated by contact with an original traumatism that produces a scarred interiority inaccessible to consciousness and reflection, a subject that wants to repeat compulsively the origin of the trauma, a subject that becomes what Lévinas calls a recurrence of the self without identification, a recurrence of trauma that is open to death, or-better-open to the passive moment of dying itself (le mourir même), dying as the first opening towards alterity, the impossibility of possibility as the very possibility of the ethical subject. (Critchley, 1999, pp. 238-239)

Critchley links Freud's trauma and an ego that can derive masochistic enjoyment from repeating certain injuries to Lévinas's ethical subject who also enjoys repeating this preconscious trauma through an "experience of the subject interlocuted by the other" (1999, p. 233). The effect of such a reduction is to deem every ethical relation masochistic, subsuming all ethical action under the sign of the death drive.

In a conclusion similar to Freud's, Critchley surmises that natural ethics is a form of masochism: the "Lévinasian subject is a traumatized self, a subject that is constituted through a self-relation experienced as a lack, where the self is experienced as the inassumable source of what is lacking from the ego - a subject of melancholia, then" (Critchley, 1999, p. 240). A review of Critchley's article thus leads us to understand two important differences between Lévinas and Freud on conditions of unknowability in the subject. First, the anarchic relation to the other is significantly not a sensible experience of (masochistic) pleasure for Lévinas. Second, the other does not indicate a lack in the self but enables the self's fulfillment as an ethical subjectivity. The equivocation Critchley finds Lévinas making between persecution and traumatism by saying "Persecution is a traumatism," enables our use of traumatism for reflecting on persecution in the self that Critchley exploits for his analysis (Critchley, 1999, p. 234).

For Critchley, ethical subjectivity in Lévinas experiences its "unconscious in relation to an original traumatism," which provides the condition of possibility for the ethical relation. Accordingly, Lévinas's notion of subjective trauma that requires an interruption by the other is what Critchley terms an "ethics as a traumatology" since the ethical subject enjoys repeating its pre-conscious trauma (Critchley, 1999, p. 233). However, Critchley's reading imagines the ethical relation as a masochistic infliction or injury because it only recalls on an affective level an original trauma by the other (Critchley, 1999, p. 235). Lévinas's emphases on negative, non-conscious, and non-definable aspects of the self that are maintained alongside the unconscious are not reduced into the unconscious. Nonconsciousness is not contained in the totality of one's ego, or "to a preconscious stage or to a repression which would suppress them" (Critchley, 1999, p. 235). Nonconsciousness and the pre-ontological condition, for Lévinas, is the feature that represses the presences of psychic structures that will organize content therein. 
Critchley has trouble understanding why Lévinas would constantly and "violently" refuse these similarities and attempts to show how Freud's thought is more similar than Lévinas would admit (1999, p. 233). Critchley finds an obvious expression of Lévinas's tense relationship to psychoanalysis in a footnote where Lévinas seems to reject the psychoanalytic concept of the unconscious while also conceiving it as what he calls "the night when the ego comes back to the self under the traumatism of persecution" (Lévinas, 1996, p. 93). A clue about Lévinas's response is found in this quote when he writes about the need to "come back" from, to traverse and cross over, that which is still on the ontological side of the self: the unconscious (p. 93). Lévinas sought that which is not any term, that which constitutes the "intentionality of intentions," in a Husserlian sense (1947, p. 46). Any sensibility whatever, even for what is lacking, is still in what Lévinas calls the hither (this) side of being (1998, p. 71).

"The night when the ego comes back" is neither the desire for a void nor the lack of libidinal excitement from empirical objects for Lévinas, but rather a "universal presence, an absolutely unavoidable presence" (Lévinas, 2001, p. 58). As such, it cannot be similar to the death drive in Freud, which is the subject's compulsion to return to a static, inorganic state. The unconscious, or nocturnal space, must be traversed, crossed, and passed over for glimpsing the trace of a persecuted subject that is traumatized in its individuated participation in being. Trauma for Lévinas is a confrontation of all that exists, all there is and all possible labels we may take upon ourselves, or what Lévinas calls the "il $y$ a." In this way, Critchley subjects Lévinas's alterity to the unconscious drive for annihilation, reaching the odd conclusion that the ethical relation must then be a masochistic pleasure - $a$ fulfillment of the death drive - according to Lévinas's own understanding of subjectivity.

With all that Critchley has right in understanding the value of traumatism and persecution in Lévinas's ethic, his reading here seems to belie the same superficial reading that he accuses most secondary literature on Lévinas of conducting, which (according to Critchley) do not proceed from a "rigorous distinction between consciousness and subjectivity" (Critchley, 1999, pp. 232-233). Even if Critchley's account is useful for finding similarities between Freud and Lévinas's concept of trauma and its role in subject formation, it must nevertheless contain the significant caveat that to understand Lévinas's ethic this generalizing reduction to a psychic trauma cannot be ultimately maintained. For Lévinas, the dynamism between a subject's infinite possibilities and totalized categories makes up every moment. Any dislocation and disjunction of the self is not an aberration to be overcome. Because the self is essentially an activity, and contemplation its action, then any intention or enjoyment does not constitute the self, but rather arises in the responsible distance that is kept between these varied experiences.

Lévinas's approach to a self that cannot be totalized by any ontic identification, but that is present only as the events forged in it, provides grounds for thinking through an egalitarian particularism that will not depend on any particular type of self. All conscious existents equally take their self very seriously; at the same time, the particularity of their existence can neither be exhaustive of nor exclusive to all types of existents that are preoccupied 
with the plenum offered in their own experiences. The pre-ontological ground of which Lévinas speaks, however, regards a view of existence and of the type of being that a subject is in the activity of its very formation. We have view of a subject that is constituted in the acts of its multifarious cognitions, intentions, and sincere enjoyments. The view here is of a dynamic subject who is also completely wrought by non-conscious, primordial instincts, including a freedom in its lag from the present. Critchley's reading of Lévinas, finally, incorrectly reduces any ethical relation to one that picks at an egoical lack, rather than seeing how it fulfills a relation between subjectivities. Proximity, traces, obsession, and subjectivity are aspects of alterity qua nonconsciousness that enable one to find selffulfillment in the other.

The egregious error for ethical subjectivity comes from its conviction that any means are justified for convincing others of one's worldview. The error is most obvious when violent means are used to persuade others of a worldview that forgets the infinite alterity, or what Lévinas (1969) calls "the face of the other." Furthermore, Freud is helpful for understanding the desire not-to-know one's perpetual partiality. What might this say about the clinging to a moral or cultural idea at the expense of the needs of the physical body the other requires? One important moral consequence of taking the indeterminate and unknowable aspects of the persecuting subject seriously is that the pain of a suffering body becomes more real and sincere than the veracity of any one idea, identification, or cultural norm.

More problematic in our approach to the evil in persecution is that thought cannot reflect on the motives in cases of delusions of persecution. For Freud, an internal desire is projected outwards, becoming an external perception that is experienced as antagonistic. As a way of managing the conflict between desire and moral obligation, the other is sacrificed in the psyche's attempts to rid itself of unacceptable impulses and desires. The one persecuting as much as the one who is being persecuted cannot think the problem away. Similarly, with Lévinas, persecution is that which makes us pursue egoical definitions as a necessary condition for having an ethical relation with the other. Undoing processes of identification on a regular basis would leave one without either thought or a self. This approach likewise does not address how delusional forms of persecution reflect one's own guilt for failing to realize social standards and how seemingly rigid - but always only contingent - thoughts, moral ideas, and representations make up the self and other.

But where do these standards and cultural ideals come from and who are the dominate groups that enforce them? These are as fluid as the identifications attributed to oneself, which makes anyone equally vulnerable to standing in relations of sameness or otherness in different times and places. Historical testimonies and developed ethos may attempt to prevent persecution; however, the stronger these ethoses are held, the more they inevitably become persecutory. There will always be the other for whom certain ideals will not apply, and those who will not agree and comply. Until bodies are turned to dust, the unbearable knowledge for one's ability to use persecutory means is a fundamental vulnerability and a natural barbarism, the conditions of which I will attempt to understand in the next final section. 


\section{Vulnerability to Subjective Unknowability, Persecution, and the Ethical Bind}

On the one hand, vulnerability as it is understood in Totality and Infinity presents the reader with the face of the other, the other who must be preserved in their strangeness (Lévinas, 1969, p. 73). Composed of significations, identifications, speech, and distance, each subject can be host to the other (Lévinas, 1969, p. 299). The face is not phenomenal and so its "appearance" does not register the color of one's eyes or the contour of one's nose; rather it becomes attuned to a particular infinitude by negating the finitude of phenomenal appearances (Lévinas, 1969, p.196). The plurality of each particular subjectivity is not smothered by but rather originates from this face-to-face encounter that preserves separation, generating an openness that goes beyond the separate being of each.

In Richard Cohen's (2010) chapter titled "Some Notes on the Title of Totality and Infinity," he shows how Lévinas's pairing of these two terms already provides a clue to his ethics. If we take seriously the claim that Lévinas's whole endeavor is to rethink the concept of vulnerability, then the title that pits infinitude against totality initiates an ethical cry "that impels thinking and being [that] is not wonder or disclosure but closer to the bone, as it were, it is human vulnerability and the moral responsibility it elicits" (2010, p. 112). Moral obligations and responsibility have recourse to infinity, pointing towards that which goes beyond any finite description, identification, totalization, ideal, and maxim.

Cohen continues that Lévinas announces a going toward the other person who remains unsubsumed, truly other in a "love thy neighbor" that does not follow from love of the self, but from one who "is" invested with and in a greater exigency than its own being. Ironically, this approach to ethics does not call for an altruistic will since one's needs can only be met, selfishly, in this difficult relation to the other. It is to put the morality and suffering of the other before one's own because the self is found there. In an always-renewed reversal of the priority that had hitherto determined philosophy, "love of wisdom" operates in the service of the "wisdom of love" (2010, p. 113). I may add that this is a non-erotic, unsentimental form of love. Often called a disruption, the "metaphysical desire" implicitly driving one toward exteriority for the other inherently puts the self-sufficient, totalized subject in question (Lévinas, 1969, p. 82). Understood in light of the relational subject who is ruptured, the disruption should not be healed into a totality with the other; rather, a mutual dis of the ruptured ego forms a relational intimacy with another. One has to constantly watch over language and relations of proximity so as not to turn each into a harmonized image of oneself. How do we keep watch over this new type of difficult freedom that requires preserving the other as other?

After finding in Totality and Infinity (1969) a theory of desire, openness, and the foundation of a self that can be hospitable, Lévinas presents a hostile and persecutory subject in Otherwise Than Being (1998). Both the hospitable and hostile aspects of an ethical subjectivity rest on a constitutional vulnerability. Responsibility for the other rivets the subject in an accusation and a wounding. We may understand this wounding, however, as one that is only for the aspects of self that are reducible to its thematizable, egoical self-sufficiency. For the relational self, responsibility is the only way of existing; for the relational 
subjectivity, the self is a safeguarding of - and is safeguarded by - the other. The preontological commitment is one way that Lévinas shows how each is capable of having this relationship that can be simultaneously so morally restricting and liberating.

A pre-ontological relation "is a relationship without any a priori which arises from a spontaneity, not from that which ontology requires in a finite thought. For, in order to welcome entities in finite thought, a pure receptivity, must operate as a transcendental imagination, formative of the imaginary" (Lévinas, 2001, p. 194). Empathy is such an automatic response that once the suffering of another is sensed it cannot be avoided. Indifference is an a posteriori option that follows only after the pre-ontological relation yields knowledge of suffering. No mitigating idea — no representational content, delusion, identification, apology, or even logos - justifies suffering, not even when it is believed to serve a divine purpose. For this reason, Lévinas found that theodicies, as much as any single normative moral standard, can be dangerous insofar as they seem to relieve one of the bare obligation to sense another's suffering and proffer a response.

The need to engage in fanciful machinations - to explain away and justify any suffering such as "it's too far from me," "I don't know these others who are suffering," or "their suffering is deserved"- - are already responses to the demand that suffering as such makes on each individual. For Lévinas, the only condition that makes the pre-ontological relation a ubiquitous ethical demand possible is the bare suffering of a body that can unexpectedly crash into another's sensed reality. The vulnerable body that is then capable of finite thought, capable of forming its existence through imagination, deserves protection.

To pose the question "who is responsible for this vulnerability?" is to indict everyone. All must be vigilant about the vulnerabilities in the self and the other that necessarily attend to being a sensible subject since these constitute the relational subject. One reason that the most vulnerable populations do not frequently receive aid is because they are unable to provide testimony about their traumas. If we imagine sensibility as the criteria that earns any refugee fleeing violence its status, then many more will appear as worthy of need and aid, even when they themselves cannot articulate their conditions as such.

We also see in this the difficult implications of loving a neighbor, not just ensuring that we love correctly, but also that we do not subsume the other in our love. How can we ensure those restrictive measures in the ways we love and relate to our neighbor are not excessively limiting, such as to induce psychological defense mechanisms like in neurosis or delusions? Sounding similar to Freud, Lévinas writes on what he calls "amphibology," which is the ambiguity implicit in any attempt to essentialize or nominalize a relation; as he writes, all of "ontology is stated in the amphibology of being and entities" (Lévinas, 2001, pp. 41-42). Given a primordial ambiguity in the ways one particular self seeks to relate, and finds a response in the other, any imperative made by means of logic and reason will remain precarious. There can be no fixed essence, rule of action, or context capable of deeming any standard secure from abuse, injustice, or the error of forgetting the unknowable, relational, and vulnerable self. 
A major thrust of Lévinas's corpus on ethical relations emphasizes the infinite regress in the self that fights against the constant attempt to totalize itself. The subject who is intersubjective, developing by and through others, is key for understanding the shocking language Lévinas uses in his chapter on substitution. In order to understand how the other gestates in the same and how, pre-ontologically, one identity comes to exist through another, we will work through the analogy of "maternity, which is bearing par excellence, bears even responsibility for the persecuting and persecutor" (Lévinas, 2001, p. 75). The immediacy between a mother and the child she bears signifies her vulnerability, just as the gestation of one's suffering in another makes one's vulnerability sensible and so non-gratuitous.

A body cannot explain away the use of its organs as it is shared with a fetus. As the pregnant female body breathes, the fetus is affected. Using this image to understand what it means to become an ethical subject can also reduce the seeming paradox of calling the ethical relation a persecution, as readers like Ricœur have contended. A shift in perspective from the egoical self to the unknowable, vulnerable, and relational self will be enacted first in order to explain the differences between the ontological and ethical dimensions of the self.

Lévinas writes that the face has no representation yet is an obsession that makes one go outside oneself. He makes an interesting distinction between modalities of obsession. One modality of obsession is when the self goes toward itself, where the ego "like a relation between monads prior to the opening up of doors or windows, in a counter-direction from intentionality" is in "nowise a development of this [ethical] relationship" (Lévinas, 1998, p. 192). A culture dominated by taking selfies that are shared with others illustrates this ego that is obsessed with itself. Another illustration is the masochistic pleasure that comes from repeating psychic trauma. This modality of obsession is what Levinas calls "erotic alterity": that is, pleasure found in compulsively engaging one's psychic traumas, as Freud illuminated in his theory of the death drive in which a psyche seeks to master trauma and excessive excitations through repetition. The more one goes toward another who is not like oneself, the bigger the risk for disturbance and disappointment because the other becomes less manageable. The other risks self-mastery and the ego's desire for omnipotence.

If we continue to work through the image of the mother's egoistic self, then her fetus is a parasite that greedily absorbs her resources. Those nutrients are taken from the mother and used for the fetus's bodily development. Eventually, this fetus will grow to walk out into the world without her. The fetus limits its mother from reaching egoical and ontological fulfillment from its earliest phases, and ultimately in pursuit of its life can neglect whatever potentialities existed before its arrival. In this modality, asymmetry exists in the mother's ultimate passivity. Her inability to escape from or decline the weight of this commitment to the fetus' demanding need, dependence, and relation "persecutes her." The use of her resources affects her in a most personal way in the same measure that this appropriation also cannot be explained away to her dependent fetus. Seen from the perspective of the (mother's) isolated ego, the fetus could even be seen as hostile in its appropriation of the very resources that the mother needs to survive; in supporting her fetus, the mother is often deprived of physical health. She is also responsible for the child's life and holds a limitless 
guilt for this pre-ontological obligation, even as the mother's ego may convince itself that she is not responsible for the fetus. Maternity as an analogy for the persecuting ethical relation breaks down in its limited view of one sex. Namely, it would be wrong to say that only females (or only those reproductive bodies capable of becoming pregnant and giving birth) bear ethical responsibility for their children. It would also be incorrect to say that a mother bears the responsibility for everything the child will do. It would be just as incorrect to say that she is the mere facilitator of the ethical possibility her male child can bear, as Donna Brody addresses in 'Lévinas's Maternal Method from 'Time and the Other' Through Otherwise Than Being, No Woman's Land?” (2001). The analogy between ethical subjectivity and maternity breaks down in these cases because, for Lévinas, the intersubjective vulnerability that maternity illustrates is common to any ethical subjectivity.

The egoical aspect of the self - a relation with the other that goes through the self, or the same as the self-is necessary for an ethical relation; however, the egoical self is not sufficient for Lévinas's view of the persecuted subject that prioritizes preservation of the other, as such. Both the self and other risk becoming lost in identifications that are made and projected onto one another. The child does not represent the alterity of a general other, but rather bears the development of a more difficult relationship with a particular other. The child shares traits with the body in which it gestates, and so shares some of its same qualities. Still, the example is helpful for understanding the dynamic dichotomy that structures the relation between the ontological and egoistic sense of self with the preontological, relational and ethical one.

Switching modalities from the ontological to the ethical (and taking the point of view of the relational self in the modality of the one-for-the-other), the mother is perceived as a host to her fetus. Maintaining her health is for the other in her, a child who is encouraged to become independent. The fact of its growth and eventual departure, however, is of no importance to the hospitality she offers. She will even take pride in empowering her child to lead an independent life in spite of the loss and, as such, she will expose the immediate vulnerability of her egoical self to the other, her child. The mother's encouragement of the other that gestates in the same is not carried out in order to preserve what she knows of herself; nor is it valued as reflecting her accomplishments. Instead of the egoistic concern, this empowerment is done for the wellbeing of the other person. Even if it is difficult to empirically verify when these modalities are engaged, it is reasonable to imagine that the mother's "being is put in question by the alterity of the other, before the intervention of a cause, before the appearing of the other" - that is, even before the child is born (Lévinas, 2001, p. 75). The passivity inherent in her vulnerability to this particular fetus already bears her ethical responsibility; after this, any further moral judgment may follow in their particular ontological relations.

Lévinas calls the "modality of obsession" one that appeals to the relational self (Lévinas, 1998, p. 192). Obsessed by another, the pre-ontological ethical dimension of subjectivity is not restricted to specific sexed or gendered relations. Expanding from the female body to parenthood and personhood, Lévinas calls "substitution" the condition of any ethical 
subjectivity, where "The expression by each monad of all the others refers to substitution, in which the identity of subjectivity is resolved. The ego obsessed by all the others, supporting all the others, is an inversion of intentional ecstasy. In passivity the ego is a self under a persecuting - accusation of a neighbor" (1998, p. 192). "Expression" is Lévinas's term for language that is not restricted to ontic speech, to what he later calls "the said."" Expression can be revealed through mediums other than what is said by the concerns, worries, desires, and ethical responsibilities of its speaker (Lévinas, 1969, p. 297). Intentional ecstasy, or ekstasis, undergoes an inversion here since it is not directed from one perceiver toward an external object. Instead, inverted intentionality is an affective relation between two subjects that mutually constitute them as ethical.

Traditionally in phenomenology different forms of intentionality constitute perceived objects. In what we can include under the intentionality of search, here Lévinas inverts the constituting gaze, which comes from the other to constitute oneself. Theodor Adorno's art object, which can open its eyes at the viewer for an aesthetic shock, is similar insofar as it comes from without to constitute an aspect in oneself. Adorno emphasizes the magic that happens between an observer and a painting when artworks "open their eyes" to look back at the observer. "What nature strives for in vain, artworks fulfill; they open their eyes" in a logic that is not given by the perceiver, but from the amorphous primordial origin present in the perceived art-object (Adorno, 1998, p. 66). Lévinas and Freud refer respectively to an anarchical and archaic immemorial past that affects the subject. That which is anarchical and passive in oneself makes one vulnerable to the ethical engagement for Lévinas, as art can do to aesthetic sensibility for Adorno. For Lévinas, however, visual art is devoid of an ethical dimension since it totalizes what cannot be totalized in image. The height of becoming an ethical subject is founded in the anarchical shock of the infinite in an ethical relation, which is deceptively frozen in pictorial images (Lévinas, 1989, p. 137).

Relational subjectivity is similarly constituted in a response to the interruptive face of the other. Intentionality is not the bedrock for constituting essences and identities; more fundamental is this relation between intentionalities that constitute one another. In an "alterity of the-one-for-the-other, responsibility before eros," Lévinas articulates this relation that is beyond sensual pleasure, where persecuting and erotic aspects are ambivalently related for a being that has language (Lévinas, 1989, p. 137). Priority is given to the aspect and "resolution" of oneself in substitution where a relation to the neighbor is required to constitute oneself. When shocking language such as "hostage" or "persecution" is used to express this relation that culminates in the self, then it is adopted from the point of view of the egoical self that is looking at the relational self, who is involuntarily vulnerable to the other and

\footnotetext{
${ }^{1}$ Before developing his distinction between the saying versus an ontic said in Chapter 3 of Otherwise Than Being, Lévinas uses the term expression to indicate "The presence of the Other, or expression, source of all signification, is not contemplated as an intelligible essence, but is heard as language, and thereby is effectuated exteriorly" (1998, p. 297).
} 
attempts to make sense of the self's own suffering. Traditional moral and political philosophies have been dominated by this view that comes from an egoical, rational self that must justify its relation to others.

The ethical saying that comes through the malice and persecution of a subject is not as paradoxical as readers like Paul Ricœur have contended. The paradoxical ethical condition that rests on this extreme degree of passivity, persecution, and hostage-taking requires shifts in perspective from the egoical self to the relational, vulnerable subject as a way of understanding Lévinas's claim. Keeping in mind the two modalities of obsession, and mother as phenomenal articulation, it is worth reviewing the full passage where Ricœur expresses his outrage at Lévinas's claim:

The Self occupies the place of the other without having either chosen or wished to do so. The "despite oneself" of the hostage condition signifies the extreme passivity of the injunction. This paradox - of an inhumane condition called upon to say the ethical injunctionshould be shocking. The non-ethical says the ethical solely by virtue of its excess. If substitution must signify something irreducible to a will to suffer, in which the Self would recovery mastery over itself in the sovereign gesture of the offering, of obligation, then it must remain an "expulsion of self outside of itself $[\ldots]$ the self emptying itself of itself" $(O B, 110-111)$. In short, it must be by its "very malice" that persecuting hatred" $(O B, 111)$ signifies the "subjection through the other" of the injunction under the aegis of the Good. I wonder whether Lévinas's readers have assessed the enormity of the paradox that consists in having malice say the extreme degree of passivity in the ethical condition. It is "outrage," the height of injustice, that one asks to signify the call to benevolence: "It is through the condition of being hostage that there can be in the world pity, compassion, pardon, and proximity" $(O B$, 117). That is not all, the "trauma of persecution" $(O B, 111)$ must also signify the "the irremissibility of accusation" $(O B, 112)$, in short, limitless guilt. Here Dostoyevsky takes over from Isaiah, Job, and the Koheleth. Here we have a kind of crescendo: persecution, outrage, expiation, "absolute accusation, prior to freedom" .... Does this not constitute an admission that ethics disconnected from ontology has no direct appropriate language of its own? (2004, p. 92, emphasis added)

Ricœur articulates nicely why many have abandoned Lévinas's ethic as capable of informing any normative moral theory or standard. There is no simple way to accept this infinite guilt and responsibility as pre-ontological, to accept persecution as a necessary condition for ethical subjectivity. However, we can reinvigorate this dilemma by differentiating between the two modalities of an egoical and relational subject.

From the perspective of the egoical subject, it is indeed an outrage to be hailed into responsibility since each is self-sufficient in providing for itself. From this perspective, the requirement of another for one's own self-realization is an outrage, a persecution. Why should anyone have to endure an expulsion outside the (egoical and partial) self toward the other (egoical and partial) self? However, it is not really an "expulsion" so much as a going toward the relational-self to constitute the ethical subject. The exilic condition enables the finding of oneself in the other; the real sense of self-ethical subjectivityrequires its others. 
We may wonder along with Ricœur how this call to passivity, which is disconnected from ontology, bears on one's particular moral strength. How can one be morally praiseworthy if one does not choose the ethical relation? In other words, Ricœur takes this as an admission that "ethics disconnected from ontology has no direct, appropriate language of its own," and so attempts to mitigate Lévinas's position through its implications for a politically just life in the rest of his article (2004, p. 92). We may take another tack, however, to preserve the extreme language of ethical subjectivity by using the two modalities of self just articulated.

The condition of taking the egoical self as a hostage for the relational self is not "inhumane" but provides grounds for both aspects of self. Passivity in the alterity of each explains the unavoidable capability of sensing another's suffering while at the same time implicates each in what is more humane. From the perspective of a relational self that requires the other for any self-fulfillment as ethical subjectivity, it is the egoical self-sufficiency that is an outrage. How can one become what one is without a passivity in alterity that welcomes the irreducible difference of the other? A posteriori the passivity can become either hostile or hospitable to the other, but the adventure is worthwhile if it means reaching a new height of intersubjectivity.

Ethics disconnected from ontology is the condition that makes all normative moral standards possible. Passivity here is not a call to benevolence, which already names a normative standard, but instead is the grounds that provide any morality, sensibility, and thought. Lévinas writes, "The recurrence of the self in responsibility for others, a persecuting obsession, goes against intentionality, such that responsibility for others could never mean altruistic will, instinct of 'natural benevolence,' or love" (1947, p. 112). The self can only proximately grasp the other in indirect traces for which an intentionality of search is necessary. There are many more direct and contextually sensitive standards that are articulated through language that follow from this basic realization of a subject who is both persecuted to live with others, but who also always pursues a moral life. Crystallizing any one standard or aspect of self as self-sufficient for a subject who can be moral in many different, ambivalently related ways is to do an injustice to the ethical ground of the self.

There are other normative standards that Ricœur names in the passage. He also names the altruist who chooses to willingly suffer for the other and as such "recovers mastery" of the egoical self (2004, p. 92). We also hear an egalitarian vulnerability in the need for all selves to empty their (egoical) self, as well as to find a virtue ethic in the possibility of recovering mastery of the relational self in a "sovereign gesture" (2004, p. 92). "Limitless guilt" sounds like the ascetic who is never complete in releasing itself from sensual pleasures all through life; in this same way, there is a limitless need to constantly forge relations and bear its consequences for Lévinas. Ricœur confounds these normative standards taken from the egoical aspect of self with the pre-ontological grounds that condition these different ways of relating with others. 
The subject cannot choose to decline its totalized aspects and as such is pursued and persecuted by the infinite ability to remain other in oneself. On the other hand, the relation between two infinite subjectivities also always remains "unassumable like a persecution" since the particularity of each relation is unique and never to be repeated again (Lévinas, 2001, p. 87). The multifarious ways in which relations are forged, such as those Ricœur names, are so preoccupying that the bare ability to navigate them is taken for granted. If the self can also be for the other, then in being for the other, one is also for the self. In one sly move, altruism and egoism are preserved by modalities that are preserved and ambivalently related in ethical subjectivity. However, the anterior condition in this ethic resides in the self's capacity also to delude itself about its egoical self-sufficiency.

An egalitarian morality can help articulate the ways in which all are equally vulnerable to the demand the face makes. The face does not appear in any phenomenal terms, such as shape, size, color, or a configuration of its parts. If one is capable of suffering, and suffering comes from the exposed body, then a demanding face is sensed, giving rise to a response and as such, responsibility. However, to the extent that an egalitarian response sets the same response for everyone, it cannot be appropriate for the needs of each particular face. Each particular body and context requires different aids, attention, and testimony for a reciprocal teaching.

Some questions relevant for extending this approach can be found in asking why one population is found to be offensive to another, why some bodies are neglected because they interrupt the social order? In our account, using Freud and Lévinas shows how representational content is the main impetus for deriding someone as a threatening other. Both share a view of subjectivity as that which is never complete, is never totally what it seems. Lévinas's view of the ethical and relational subject who finds a new self in its confrontation with the other has enabled an ascent out of the abyss of unknowability under the Freudian hermeneutics of suspicion. My use of the mother as an illustrative example for the egoical and relational modalities of ethical subjectivity has not been intended to implicate one sexed or gendered body as most responsible for the other. ${ }^{2}$ Instead, the example intends to show the mutually obligating risk of standing in relation to those who cannot be known, who can appropriate one's resources, and whose actions cannot be anticipated. All sexed and gendered bodies can usefully learn from this vulnerable relation that leaves one dependent on an other. We are here reminded of the Socratic insight that the wisest are aware of an incapacity to fully know. The examination of life is what makes knowledge and life worthwhile, not any one single answer. Philosophy's beginning in wonder was quickly foreclosed by the perceived inability to distinguish right from wrong, good from bad. We often furiously respond to that wonder with totalized forms of knowledge and imperialistic sciences, which indicate our discomfort in a relation that remains unknown and unknowable in itself. Lévinas opens the possibility of relating to others, albeit in ways that keep us vulnerable, and where discernment is difficult. Freud more fully articulated

\footnotetext{
${ }^{2}$ See Jacqueline Rose in Mothers: An Essay on Love and Cruelty (2018) for further limits and advantages of using the image of the mother in discourses on ethics.
} 
the psychic effects of moral injunctions that value mastering egoical and individuated desires, risking a blindness to others, such as in neurotic paranoia and delusions of persecution. In response to this, I find that Lévinas's emphasis on the infinite aspect of ethical subjectivity and the pre-ontological condition of persecution also acknowledges a fundamental insufficiency of knowledge, however, shifting perspectives to relational subjectivity successfully articulates the ability to suffer in which we are, at the very least, capable of responding to the particular suffering of others.

\section{References}

Adorno, T. (1998). Aesthetic Theory. (R. Hullot-Kentor, Ed.). London, UK: Continuum.

Brody, D. (2001). Lévinas's Maternal Method from "Time and the Other" Through Otherwise Than Being: No Woman's Land? In T. Chanter (Ed.), Feminist Interpretations of Emmanuel Lévinas (pp. 53-77). Pennsylvania: The Pennsylvania State University Press.

Cohen, R. (2010). Lévinasian Meditations: Ethics, Philosophy, and Religion. Pittsburgh, PA: Duquesne University Press.

Critchley, S. (1999). The Original Traumatism: Lévinas and Psychoanalysis. In R. Kearney \& M. Dooley, (Eds.), Questioning Ethics: Contemporary Debates in Continental Philosophy (p. 230-242). London, UK: Routledge.

Freud, S. (1955a). The Standard Edition of the Complete Psychological Works of Sigmund Freud. (Vol. XVII, 1917-1919): An Infantile Neurosis and Other Works, pp. 1-287. (J. Strachey, Ed.). London, UK: The Hogarth Press and the Institute of Psycho-analysis.

Freud, S. (1955b). The Standard Edition of the Complete Psychological Works of Sigmund Freud. (Vol. XVIII, 1920-1922): Beyond the Pleasure Principle, Group Psychology and Other Works, pp. 1-283. (J. Strachey, Ed.). London, UK: The Hogarth Press and the Institute of Psycho-analysis.

Freud, S. (1958). The Standard Edition of the Complete Psychological Works of Sigmund Freud. (Vol. XII, 1911-1913). The Case of Schreber, Papers on Technique and Other Works, pp. iivii. (J. Strachey, Ed.). London, UK: The Hogarth Press and the Institute of Psycho-analysis.

Lévinas, E. (1969). Totality and Infinity. (A. Lingis, Ed.). New York, NY: Duquesne University Press.

Lévinas, E. (1989). The Lévinas Reader. (S. Hand, Ed.). Oxford, UK: Blackwell Publishing.

Lévinas, E. (1996). Basic Philosophical Writings. (A. T. Peperzak, S. Critchley, and R. Bernasconi, Ed.). Chicago, IL: Indiana University Press.

Lévinas, E. (1998). Otherwise Than Being: Beyond Essence. (A. Lingis, Trans.). New York, NY: Duquesne University Press.

Lévinas, E. (2001). Existence and Existents. (A. Lingis, Trans.). New York, NY: Duquesne University Press. (Original work published 1947) 
Ricœur, P. (1970). Freud and Philosophy: An Essay on Interpretation. New Haven, CT: Yale University Press.

Ricœur, P., \& Escobar, M. (2004). Otherwise: A Reading of Emmanuel Lévinas's Otherwise than Being or Beyond Essence. Yale French Studies, Encounters with Lévinas, 104, 82-99. 